\title{
Role of multiple gene copies in particulate methane monooxygenase activity in the methane-oxidizing bacterium Methylococcus capsulatus Bath
}

\author{
Sergei Stolyar, ${ }^{1}$ Andria M. Costello, ${ }^{3}$ Tonya L. Peeples ${ }^{3} \dagger$ \\ and Mary E. Lidstrom ${ }^{1,2}$ \\ Author for correspondence: Mary E. Lidstrom. Tel: +1 206616 5282. Fax: +1 2066165721. \\ e-mail: lidstrom $\hat{a}$ u.washington.edu
}

1,2 Departments of Chemical Engineering ${ }^{1}$ and Microbiology², University of Washington, Box 351750, Seattle, WA 98195 , USA

3 Environmental Engineering Science 13878, California Institute of Technology, Pasadena, CA 91125 , USA

\begin{abstract}
Genes for the subunits of particulate methane monooxygenase, PmoABC, have been sequenced from the $\gamma$-proteobacterial methanotroph Methylococcus capsulatus Bath. M. capsulatus Bath contains two complete copies of pmoCAB, as well as a third copy of pmoC. The two pmoCAB regions were almost identical at the nucleotide sequence level, differing in only 13 positions in $3183 \mathrm{bp}$. At the amino acid level, each translated gene product contained only one differing residue in each copy. However, the pmoC3 sequence was more divergent from the two other pmoC copies at both the far $\mathrm{N}$-terminus and far C-terminus. Chromosomal insertion mutations were generated in all seven genes. Null mutants could not be obtained for pmoC3, suggesting that it may play an essential role in growth on methane. Null mutants were obtained for pmoC1, pmoC2, pmoA1, pmoA2, pmoB1 and pmoB2. All of these mutants grew on methane, demonstrating that both gene copies were functional. Copy 1 mutants showed about two-thirds of the wild-type whole-cell methane oxidation rate, while copy 2 mutants showed only about one-third of the wildtype rate, indicating that both gene copies were necessary for wild-type particulate methane monooxygenase activity. It was not possible to obtain double null mutants that were defective in both pmo copies, which may indicate that some expression of pMMO is important for growth.
\end{abstract}

Keywords: methane monooxygenase, methanotroph, duplicate genes, $p m o$

\section{INTRODUCTION}

Methanotrophs are a group of Proteobacteria that utilize methane as a sole source of carbon and energy (Hanson et al., 1990). The initial transformation involves the conversion of methane to methanol by methane monooxygenase (MMO). Two types of MMO are known, a cytoplasmic or soluble form (sMMO) and a membranebound or particulate form ( $\mathrm{pMMO}$ ). All known meth-

\footnotetext{
†Present address: Dept of Chemical and Biochemical Engineering, University of lowa, lowa City, IA 52242, USA.

Abbreviations: $\mathrm{pMMO}$, particulate methane monooxygenase; sMMO, soluble methane monooxygenase; NMS, nitrate mineral salts medium; NMSF, NMS medium containing iron and formate.

The GenBank accession numbers for the sequences reported in this paper are L40804 (for the fragment containing pmoC1), U94337 (for the copy 2 pmo gene cluster) and AF091320 (for the fragment containing pmoC3).
}

anotrophs contain the pMMO, but the sMMO is found in only a few methanotrophs, as a second enzyme (Hanson et al., 1990; Koh et al., 1993; Nakajima et al., 1992). In those strains that contain both enzymes, sMMO is expressed only under copper-limitation (Prior \& Dalton, 1985a; Smith \& Dalton, 1989). The sMMO is an NADH-linked iron enzyme with a broad substrate specificity (Colby \& Dalton, 1976; Fox et al., 1989; Green \& Dalton, 1989). The genes for the subunits of sMMO have been cloned and sequenced from Methylococcus capsulatus Bath (Stainthorpe et al., 1990), Methylosinus trichosporium OB3b (Cardy et al., 1991) and Methylocystis sp. strain M (McDonald et al., 1997). Insertion mutants in sMMO genes in Methylosinus trichosporium OB3b still express pMMO normally (Martin \& Murrell, 1995). Recent studies have suggested that in Methylococcus capsulatus Bath and Methylosinus trichosporium $\mathrm{OB} 3 \mathrm{~b}$, transcription of the sMMO 
genes is negatively regulated by copper (Nielsen et al., 1997).

The $\mathrm{pMMO}$ is a copper enzyme with a relatively narrow substrate specificity, and it contains at least three subunits, of approximately 45, 26 and $23 \mathrm{kDa}$ (Smith \& Dalton, 1989; Nguyen et al., 1994, 1998; Zahn \& DiSpirito, 1996). The $26 \mathrm{kDa}$ subunit apparently contains the active site, as it binds the suicide inhibitor acetylene (Prior \& Dalton, 1985b; DiSpirito et al., 1992). Hybridization studies have suggested that methanotrophs contain multiple copies of genes encoding the 45 and $26 \mathrm{kDa}$ subunits $(p m o B 1$ and $p m o A 1$, respectively) (Semrau et al., 1995). One copy of the genes encoding these two subunits was cloned and sequenced, and the genes were found to be adjacent to each other in the order pmoA1-pmoB1 (Semrau et al., 1995). In addition, a gene encoding the $23 \mathrm{kDa}$ subunit ( $p m o \mathrm{C} 1$ ) has been shown to be present upstream of pmoA1 (Nguyen et al., 1996). pmoA1 and pmoB1 showed substantial similarity to genes encoding the analogous subunits of a related enzyme, ammonia monooxygenase (Semrau et al., 1995), which are also present in multiple copies in nitrifying bacteria (McTavish et al., 1993; Norton et al., 1996). In the nitrifiers, the genes are also organized in a cluster in the order amoCAB with an additional, single copy of amoC (Klotz et al., 1997; Sayavedra-Soto et al., 1998). In Nitrosomonas europaea, an insertion mutant defective in one of the amo $A$ genes showed slower growth than the wild-type, while a mutant containing an insertion in the other amoA gene showed normal growth (Hommes et al., 1998). However, mutants are not available in the other amo genes. A $3.3 \mathrm{~kb}$ transcript covering $p m o A$, $p m o B$ and $p m o C$ as well as smaller transcripts are detectable in Metbylococcus capsulatus Bath and Methylosinus trichosporium OB3b expressing pMMO, but it is not known which of the sets of genes is responsible for these transcripts (Nielsen et al., 1997). Likewise, analogous transcripts have been detected in nitrifying bacteria, and it has been shown that the amoA mutant showing slower growth also has decreased amounts of these transcripts (Hommes et al., 1998; Sayavedra-Soto et al., 1998).

In this paper, we present the entire sequence of both $p m o C A B$ gene clusters and a third copy of $p m o C$ from Methylococcus capsulatus (Bath), as well as the phenotypes of insertion mutants generated in each of the seven genes.

\section{METHODS}

Bacterial strains, plasmids and growth conditions. Escherichia coli strains DH $5 \alpha$, DH $5 \alpha \mathrm{MCR}$ (Bethesda Research Laboratories), Inv $\alpha \mathrm{F}^{\prime}$ (Invitrogen) and S17-1 (Simon et al., 1983) were used in this study (Table 1). They were grown in LB medium in the presence of appropriate antibiotics as described by Sambrook et al. (1989). Methylococcus capsulatus Bath was grown on nitrate mineral salts medium (NMS) (Whittenbury \& Dalton, 1981) in batch culture at $42{ }^{\circ} \mathrm{C}$ with or without copper added as $\mathrm{CuSO}_{4} \cdot 5 \mathrm{H}_{2} \mathrm{O}(10 \mu \mathrm{M}$ final concentration), with a $1: 1(\mathrm{v} / \mathrm{v}) \mathrm{CH}_{4} /$ air ratio in the head space, or on agar plates with the same medium. In some cases
NMS without copper, with $0.5 \mathrm{mM}$ ferrous sulfate and $1 \mathrm{mM}$ formate (NMSF) was used to grow bacteria with sMMO expressed. All M. capsulatus Bath mutants were grown from frozen cultures and tested by diagnostic PCR after growth to ensure that the insertion mutations were correct.

DNA manipulations. Plasmid isolation, E. coli transformation, restriction enzyme digestion, ligation, blunting ends with $\mathrm{T} 4$ DNA polymerase, or filling in ends with Klenow enzyme were carried out as described by Sambrook et al. (1989). The chromosomal DNA of $M$. capsulatus Bath grown in batch culture was isolated by the procedure of Marmur (1961). For the insertion mutants, chromosomal DNA was isolated from cells grown on agarose plates. In this case, cells were washed from the agarose surface using $3 \mathrm{ml}$ TEN $(50 \mathrm{mM}$ Tris/ EDTA $+150 \mathrm{mM} \mathrm{NaCl}$ ) and the liquid was collected in $25 \mathrm{ml}$ Corex tubes. Tubes were spun for $5 \mathrm{~min}$ at $10000 \mathrm{~g}$ and $4{ }^{\circ} \mathrm{C}$ and the supernatant poured off. The pellet was resuspended by adding $3 \mathrm{ml}$ TEN with $4 \mathrm{mg}$ lysozyme $\mathrm{ml}^{-1}$ and incubated at $37^{\circ} \mathrm{C}$ for $1 \mathrm{~h}$. Next, $3 \mathrm{ml}$ TEN with $4 \%$ (w/v) SDS was added to the tubes and incubated in a $45-50{ }^{\circ} \mathrm{C}$ water bath until the solution was clear (approximately $30 \mathrm{~min}$ ). DNA was extracted using phenol and precipitated using ethanol by standard procedures (Sambrook et al., 1989).

DNA sequencing. DNA sequencing was carried out by the Caltech Sequencing Facility and the University of Washington Sequencing Facility, with an Applied Biosystems automated sequencer, from both strands.

DNA-DNA hybridization. DNA-DNA hybridizations were carried out with dried agarose gels as described by Meinkoth \& Wahl (1984) at $68^{\circ} \mathrm{C}$ for DNA fragment probes or $42^{\circ} \mathrm{C}$ for oligonucleotide primer probes. For hybridizations, $6 \times$ SSC $(1 \times$ SSC is $0.15 \mathrm{M} \mathrm{NaCl}$ and $0.015 \mathrm{M}$ sodium citrate) was used; for washes, $0.5 \times$ SSC was used. Dried gels are not appropriate for DNA fragments less than $0.8 \mathrm{~kb}$, and for these gels, nucleic acids were transferred to a nylon membrane $\left(\mathrm{Hybond} \mathrm{N}^{+}\right.$) by capillary blotting and treated according to the vendor's recommendation. For DNA labelling, a randomprimed DNA labelling kit (Amersham) or direct nucleic acid labelling and detection systems (Amersham) were used for radioactive or non-radioactive labelling, respectively. T4 polynucleotide kinase (Boehringer Mannheim) was used for oligonucleotide labelling.

PCR. PCR was performed in $50 \mu \mathrm{l}$ reaction mixtures in $0.5 \mathrm{ml}$ microcentrifuge tubes. Reactions were carried out in a PerkinElmer GeneAmp PCR System 9600 thermal cycler. Thirty cycles of $92^{\circ} \mathrm{C}$ for $1 \mathrm{~min} ; 55^{\circ} \mathrm{C}$ for $1 \mathrm{~min} ; 72^{\circ} \mathrm{C}$ for $1 \mathrm{~min}$ were performed followed by a final extension of $5 \mathrm{~min}$ at $72{ }^{\circ} \mathrm{C}$ to amplify fragments up to $3 \mathrm{~kb}$. To amplify fragments more than $3 \mathrm{~kb}$, the program recommended by Boehringer Mannheim for the Expand PCR System was used: 2 min at $92^{\circ} \mathrm{C}, 10$ cycles of $92^{\circ} \mathrm{C}$ for $15 \mathrm{~s}, 57^{\circ} \mathrm{C}$ for $30 \mathrm{~s}, 68^{\circ} \mathrm{C}$ for $4 \mathrm{~min}$ and 15 cycles with elongation times of $20 \mathrm{~s}$, with a final step of $72^{\circ} \mathrm{C}$ for $7 \mathrm{~min}$. Taq polymerase (Boehringer Mannheim) was used. Primers used were as follows. For the Kmcassette (accession no. X06404): KBF1 (5'-CGATAGATTGTCGCACCTG- $\left.3^{\prime}\right)$ and KBR2 (5'-CACTTTCTGGCTGGATG- $3^{\prime}$ ). For amplification of pmo genes (accession no. L40804): CSS1F (5'-CAAACAATGGCAGCAACAAC-3') 118 to $138 \mathrm{bp}, \mathrm{CSS} 2 \mathrm{~F}\left(5^{\prime}\right.$-CCTGTGGGTGCGGTGGTAC-3') 222 to $241 \mathrm{bp}$, CSSK4F (5'-GGCACTGGCCGTCATGGGCAC$\left.3^{\prime}\right) 799$ to $820 \mathrm{bp}$, CSS9F (5'-GCCACACCTTCTGGTTCATGG-3') 727 to $747 \mathrm{bp}$, CSS9R (5'-GCCTTCGTCCACGGCTTC-3') 875 to $893 \mathrm{bp}$, CSS10R (5'-AGATGAACGCCGCAAAAC-3') 601 to $618 \mathrm{bp}$, CSS16R (5'-GTGAGCCACTTCTTGTCCAGC-3') 172 to $190 \mathrm{bp}$, CSS17R (5'-GAGCT- 
Table 1. Bacterial strains and plasmids used in this study

\begin{tabular}{|c|c|c|}
\hline Strain or plasmid & Relevant trait(s) & Source or reference \\
\hline \multicolumn{3}{|l|}{ E. coli } \\
\hline $\mathrm{DH} 5 \alpha$ & 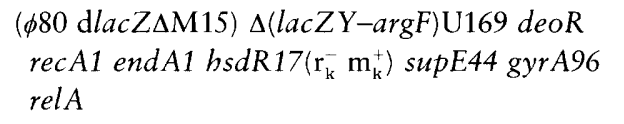 & $\begin{array}{l}\text { Bethesda Research } \\
\text { Laboratories }\end{array}$ \\
\hline $\mathrm{DH} 5 \alpha \mathrm{MCR}$ & $\mathrm{DH} 5 \propto m c r A \Delta(m m r-h s d R M S-m s r B C)$ & $\begin{array}{l}\text { Bethesda Research } \\
\text { Laboratories }\end{array}$ \\
\hline $\ln v \alpha \mathrm{F}^{\prime}$ & $\begin{array}{l}(\phi 80 \text { lac } Z \Delta M 15) \Delta(\operatorname{lac} Z Y A-\arg F) d e o R^{+} \mathrm{F}^{\prime} \\
\left.\text { recA1 endA1 hsdR17( } \mathrm{r}_{\mathrm{k}}^{-} \mathrm{m}_{\mathrm{k}}^{+}\right) \operatorname{supE} 44 \operatorname{gyr} A 96 \\
\text { relA }\end{array}$ & Invitrogen \\
\hline S17-1 & thi pro recA hsdR RP4-2-tet:: $\mathrm{Mu}$ aphA::Tn7 & Simon et al. (1983) \\
\hline \multicolumn{3}{|l|}{ M. capsulatus Bath } \\
\hline T401 & Uncharacterized $\operatorname{Tn} 5$ chromosomal insertion & This study \\
\hline MAK5 & $p m o A 1:: \mathrm{Km}^{\mathrm{r}}$ & This study \\
\hline MAK 16 & $p m o A 2:: \mathrm{Km}^{\mathrm{r}}$ & This study \\
\hline MBK1-1 & $p m o B 1:: \mathrm{Km}^{\mathrm{r}}$ & This study \\
\hline MBK206 & $p m o B 2:: \mathrm{Km}^{\mathrm{r}}$ & This study \\
\hline MCK60 & $p m o C 1:: \mathrm{Km}^{\mathrm{r}}$ & This study \\
\hline MCK62 & pmoC2:: $\mathrm{Km}^{\mathrm{r}}$ & This study \\
\hline MBS2 & $p m o B 1:: \mathrm{Sm}^{\mathrm{r}}$ & This study \\
\hline MBS202 & $p m o B 2:: S \mathrm{~m}^{\mathrm{r}}$ & This study \\
\hline \multicolumn{3}{|l|}{ Plasmids } \\
\hline pUC18/19Ap ${ }^{r}$ & lacZ & $\begin{array}{l}\text { Yanisch-Perron et al. } \\
(1985)\end{array}$ \\
\hline pCR II & $\mathrm{Ap}^{r} \mathrm{Km}^{\mathrm{r}} l a c Z \alpha$ & Invitrogen \\
\hline $\mathrm{pCR} 2.1$ & $A p^{r} K m^{r} l a c Z \alpha$ & Invitrogen \\
\hline pUC4K & $\mathrm{Ap}^{r} \mathrm{Km}^{\mathrm{r}}$ & Vieira \& Messing (1982) \\
\hline pAYC61 & $A p^{r} T c^{r}$ & Chistoserdov et al. (1994) \\
\hline pBR325 & $\mathrm{Ap}^{r} \mathrm{Cm}^{\mathrm{r}} \mathrm{T} c^{\mathrm{r}}$ & Bolivar (1978) \\
\hline $\mathrm{pBR} 325 \Omega$ & $\operatorname{pBR} 325:: \Omega S m^{r} / S^{r}$ & $\begin{array}{l}\text { C. Murrell, University of } \\
\text { Warwick, UK }\end{array}$ \\
\hline pSUP2021 & $A p^{r} K m^{r}$ & Simon et al. (1983) \\
\hline pRK2013 & $\mathrm{Km}^{\mathrm{r}}$ & $\begin{array}{l}\text { Figurski \& Helinski } \\
(1979)\end{array}$ \\
\hline pAMC100 & pUC19 with $2.9 \mathrm{~kb} \mathrm{KpnI}$ insert & Semrau et al. (1995) \\
\hline pAMC101 & pUC19 with $1.8 \mathrm{~kb} \mathrm{KpnIPstI}$ insert & Semrau et al. (1995) \\
\hline pAMC102 & pUC19 with $2.5 \mathrm{~kb} E c o$ RI insert & Semrau et al. (1995) \\
\hline pAMCIO3 & pUC19 with $1.0 \mathrm{~kb}$ EcoR insert & This study \\
\hline
\end{tabular}

GCACCACCAATGGTTG-3') 135 to $155 \mathrm{bp}$, CSS19R (5'GTACCACCGCACCCTCAGG-3') 222 to $241 \mathrm{bp}, \operatorname{ASS} 1 \mathrm{~F}\left(5^{\prime}\right.$ CTGGGACTTCTGGTCGGACTG-3') 1202 to $1223 \mathrm{bp}$. Copy 2 specific (accession no. U94337) : ESSR (5'-CCTGAACGTCTAAAATCCAGC-3') 3242 to 3262 bp. For amplification of pmoC3 (accession no. AF091320): C3F1 (5'GGCATCAATCCAACACC-3') 1 to 17 bp, C3R 1 (5'-GCGGACGGTGGCTCCCTGG-3') 855 to 874 bp.

All sequence generated by PCR was confirmed from a second, separate amplification reaction.

Computer analysis. Translation and analyses of DNA and DNA-derived polypeptide sequences were carried out using Genetic Computer Group (Wisconsin) programs and the National Center for Biotechnology Information BLAST server using the BLAST algorithm (Altschul et al., 1990, 1997). and a control strain. The $\mathrm{Km}^{\mathrm{r}}$ cassette from pUC4K and the
$\Omega S m^{r} / S p^{r}$ cassette from $p B R 325 \Omega$ were used as selective inactivating markers. pBR325 $\Omega$ was constructed in the laboratory of J. C. Murrell (University of Warwick, UK) using the omega fragment from pHP45-omega (Prentki \& Kirsh, 1984). The constructs with mutated genes were subcloned into the suicide vector pAYC61 (Chistoserdov et al., 1994) and introduced into $M$. capsulatus Bath by conjugation. E. coli S17-1 was used as donor. Matings were conducted as described by Stolyar et al. (1995). Donor and recipient cells (ratio $1 / 5-1 / 10$ ) were mixed and resuspended in NMS medium, then cells were pelleted, resuspended by pipetting in $30-40 \mu \mathrm{l}$ NMS and plated as a spot on NMS agar. Plates were incubated at $37^{\circ} \mathrm{C}$ for $48 \mathrm{~h}$ under methane/air, and then cells were transferred to selective plates. Mutants of $M$. capsulatus Bath were selected on plates with $50 \mu \mathrm{g} \mathrm{Km} \mathrm{ml}^{-1}$ or $100 \mu \mathrm{g} \mathrm{Sm}$ and $\mathrm{Sp} \mathrm{ml} \mathrm{m}^{-1}$ and screened on plates with $75 \mu \mathrm{g} \mathrm{Ap} \mathrm{ml}^{-1}$ to test for vector absence. Ap-sensitive clones were examined by hybridization to DNA blots with gene-specific and vector-specific 
probes to verify recombinational events, as well as by PCR amplification using primers for diagnostic regions.

A control strain was generated for comparative phenotypic studies in which a $\operatorname{Tn} 5\left(\mathrm{Km}^{\mathrm{r}}\right.$ gene $)$ was inserted into a random chromosomal location by using pSUP2021 and pRK2013 (as a helper plasmid). This strain shows normal growth on methane, and is able to grow on methane in the presence of kanamycin.

sMMO assay. sMMO activity was detected on plates using the naphthalene plate assay described by Graham et al. (1992). Maximum sMMO activity on plates was achieved when cells were grown on NMSF medium.

Whole-cell methane oxidation assay. Rates of whole-cell methane-dependent $\mathrm{O}_{2}$ uptake were determined polarographically using an oxygen electrode chamber at $42^{\circ} \mathrm{C}$, as described by McNerney \& O'Connor (1980). Cells were washed and resuspended in $50 \mathrm{mM}$ HEPES buffer $\mathrm{pH} 7 \cdot 0$.

\section{RESULTS}

\section{Sequencing of pmoC1}

A $2.9 \mathrm{~kb} K p n \mathrm{I}$ fragment of M. capsulatus Bath DNA had been previously cloned (pAMC100), and sequencing of the $3^{\prime}$ region revealed $p m o A 1$ and part of $p m o B 1$ (Fig. 1; Semrau et al., 1995). A $1.8 \mathrm{~kb}$ KpnI-PstI fragment containing most of pmoA1 and $1 \mathrm{~kb}$ of the upstream region was subcloned into pUC19 to generate pAMC101 (Fig. 1), and the insert was sequenced. One ORF was found upstream of pmoA1. A region near the $\mathrm{N}$ terminus starting 10 residues after the first methionine revealed an almost perfect match to an amino acid sequence (AAAEAPLKDKKWLTFA) that had been determined by Edman degradation for the $23 \mathrm{kDa}$ pMMO subunit (Nguyen et al., 1998). The only discrepancy was that the underlined lysine was predicted by the nucleotide sequence to be a leucine. This ORF was designated pmoC1 and is predicted to encode a polypeptide of 260 amino acids with a molecular mass of $29000 \mathrm{Da}$, assuming it starts at the position determined by Edman degradation. A hydropathy analysis of pmoC1 predicts a minimum of three and a maximum of six membrane-spanning regions with no classical leader sequence at the $\mathrm{N}$-terminus. A search of both protein and DNA databases revealed significant identity with amoC sequences from nitrifiers (Klotz et al., 1997; Sayavedra-Soto et al., 1998) (44-54\% identity at the amino acid level).

\section{Sequencing and analysis of the second copy of pmo genes}

Hybridization experiments had suggested that part of the second copy of $p m o B$ was located on a $1.0 \mathrm{~kb} E c o$ RI fragment (Semrau et al., 1995). This fragment was cloned into pUC19 to generate pAMC103 (Fig. 1), and the insert was sequenced. This sequence showed high identity to the pmoB1 sequence, and an ORF was present whose predicted product showed high identity to PmoB1. All attempts to clone the upstream $K p n I$ and EcoRI fragments were unsuccessful, even with low- copy-number vectors. It has been suggested that these gene products may be toxic in alternative hosts (Semrau et al., 1995). Hybridization analysis of chromosomal DNA digested with different restriction enzymes and probed with $p m o A 1, B 1$ and $C 1$ sequences demonstrated that the segment of chromosomal DNA upstream of $p m o B 2$ contained $p m o A$ and $p m o C$ sequences similar to the genes previously characterized. Therefore, the sequence of this region was obtained by PCR, using Kminsertion strains to target the second copy.

To obtain the missing sequences for the second copy of pmo $A B$, strain MBK206 containing a $\mathrm{Km}$ insertion in the $K p n I$ site of $p m o B 2$ (Fig. 1 ; and see below) was used for amplification from the chromosome. The primers targeted the $5^{\prime}$ end of pmoA2 (ASSF1) and the Kmresistance cassette (KBF1), to amplify a fragment overlapping the unsequenced region. The use of the Kmresistance insertion mutant ensured that the amplified fragment was from copy 2 , not copy 1 . A PCR product with the expected size of $1.9 \mathrm{~kb}$ was obtained. This DNA fragment was cloned into the Invitrogen vector pCR2.1 and sequenced. As expected, it contained most of $p m o A 2$ and the $5^{\prime}$ portion of $p m o B 2$.

For the region containing $p m o C 2$, probing experiments had shown that $p m o C 2$ and the $5^{\prime}$ end of $p m o A 2$ were present on a $1.4 \mathrm{~kb}$ Sall fragment (data not shown). Assuming that $p m o C 2$ was similar in size to $p m o C 1$, this SalI fragment should contain all of $p m o C 2$ and $0.4 \mathrm{~kb}$ of DNA $5^{\prime}$ to pmoC2. Attempts to clone this SalI fragment were unsuccessful. Therefore, an inverse PCR procedure was used that involved the insertion mutant MCK62, which contains a $\mathrm{Km}$-resistance gene in the $B b s \mathrm{I}$ site of pmoC2 (Fig. 1; see below for details of mutant construction). First, the appropriate size fraction of Salldigested MCK62 DNA was isolated from a gel. This pool of DNA was then ligated, which joined the SalI fragments into a circle. This DNA was then digested with HindIII, which cuts within the Km-resistance gene but not within the pmoC2 region. This procedure separated $p m o C 2$ and its upstream region into two inverted parts flanked by portions of the $\mathrm{Km}$-resistance cassette. It was then possible to amplify the entire region using appropriate primers targeted to the ends of the $\mathrm{Km}$-resistance cassette (KBF1 and KBR2). A fragment of the correct size $(2 \mathrm{~kb})$ was obtained, and it was sequenced directly as a PCR product. Based on the known sequence for the first copy of $p m o C A$ and for the $\mathrm{Km}$-resistance cassette, we identified $p m o \mathrm{C} 2$, the $p m o C 2-p m o A 2$ intergenic region and $170 \mathrm{bp}$ of $p m o A$. The sequence of the $5^{\prime}$ end of $p m o C 2$ and the region immediately upstream of the translational start site was confirmed by direct PCR from chromosomal DNA, using appropriate primers. These data completed the sequence of all three subunits of the second copy of the pmo genes.

We have also amplified $3.5 \mathrm{~kb}$ and $3.1 \mathrm{~kb}$ fragments containing the entire $p m o C A B 2$ gene cluster. The $3.5 \mathrm{~kb}$ fragment containing all three genes plus the known upstream region was amplified using a primer specific to 

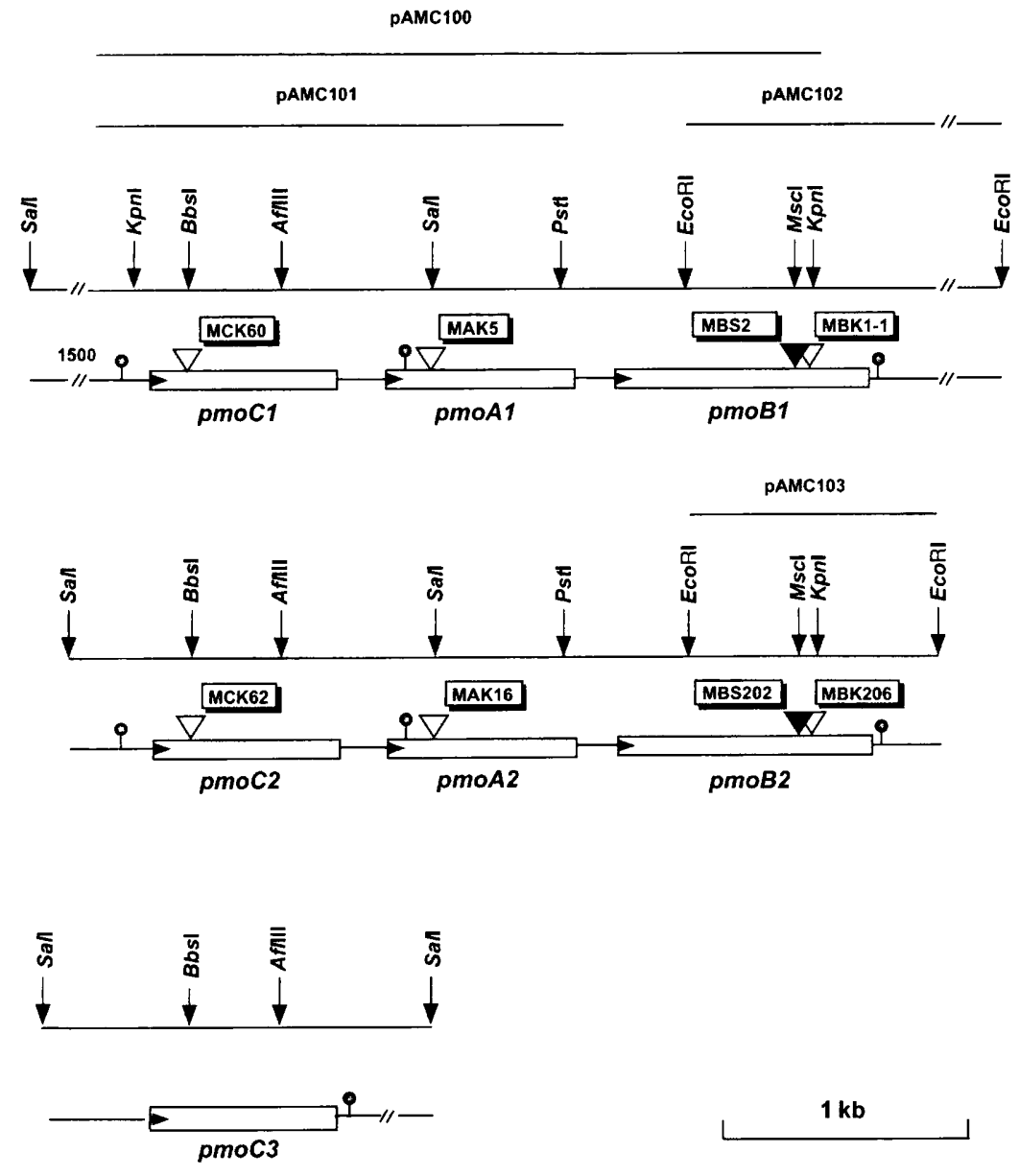

$\stackrel{5}{1}$

a region just inside the Sall site upstream of $p m o C 2$ and the ESSR 1 primer complementary to the region immediately downstream of $p m o B 2$. The primers used in amplifying the $3 \cdot 1 \mathrm{~kb}$ fragment were CSS1F and ESSR1. This produced a fragment with the same $3^{\prime}$ end as the $3.5 \mathrm{~kb}$ fragment, but with a shorter $5^{\prime}$ end that begins 6 nucleotides upstream of the start codon for pmoC2. Therefore, both fragments contain all three ORFs, but the smaller one lacks a $0 \cdot 4 \mathrm{~kb} 5^{\prime}$ region. These fragments were the expected size, confirming that the pmoCAB2 genes that have been sequenced are linked on the chromosome. We were able to clone the $3 \cdot 1 \mathrm{~kb}$ fragment using the pCR2.1 vector but were unable to clone the larger fragment. In addition, we were able to clone a PCR product containing a $400 \mathrm{bp}$ region upstream of the pmoC2 translational start site. These results suggest that the difficulties in cloning these genes are related to expression of $p m o C 2$.

The nucleotide sequence of the region containing the second copy of $p m o C A B$ was almost identical to the first copy. Starting with the ATG identified for $p m o C 1$, the sequences of $p m o C 1$ and $p m o C 2$ differ only in 3 nucleotides, which result in only one amino acid change, at residue 239, where PmoC1 contains an arginine and PmoC2 contains a serine (Fig. 2). However, the 125 bp sequence upstream of the start site for pmoC1 showed only $40 \%$ identity to the same region for $p m o C 2$. The $p m o C-p m o A$ intergenic region showed more divergence than the pmoC coding region, with differences in 5 of 164 nucleotides.

The two regions containing $p m o A B$ were even more similar at the nucleotide sequence level, differing in only 5 out of 2236 nucleotides. The predicted amino acid sequence of PmoA1 differs from that of PmoA2 only at residue 173, where PmoA1 contains an asparagine while PmoA2 contains a tyrosine. Likewise, the predicted amino acid sequences of PmoB1 and PmoB2 differ only at residue 385 , where $P$ moB1 contains a serine instead of an arginine in PmoB2. The pmoA1-pmoB1 and $p m o A 2-p m o B 2$ intergenic regions are identical. The sequences of the two gene copies begin to diverge 80 nucleotides downstream of the termination codon for pmoB, after which the identity drops to $35 \%$. Immediately before this divergent point are conserved sequences that could form a double-hairpin structure with a calculated $\Delta G^{\circ}$ of $-194.6 \mathrm{~kJ} \mathrm{~mol}^{-1}(-46.5 \mathrm{kcal}$ $\mathrm{mol}^{-1}$ ) for copy 1 and $-204.3 \mathrm{~kJ} \mathrm{~mol}^{-1}$ (-48.8 kcal $\mathrm{mol}^{-1}$ ) for copy 2. This structure is a candidate for a transcriptional terminator. Because of the similarity in the sequences of the two copies, in all cases they were sequenced at least twice from different DNA preparations, and in each case the sequences agreed exactly. 
PMOC3 MATTTAGGIAAIDRLLLDKKWLVFAIGIYTVFYLWVRWYEGVYGWSAGLDSFAPEFETYW

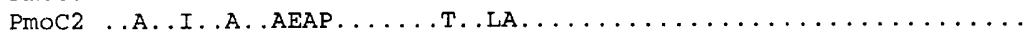

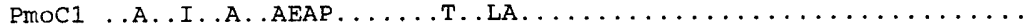

MNFLYTEIVLEIVTASILWGYLWKTRDRNLAALTPREELRRNFTHLVWLVAYAWAIYWGA

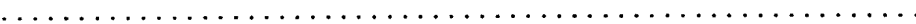

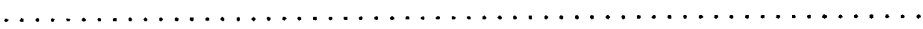

SYFTEQDGTWHQTIVRDTDFTPSHI IEFYLSYPIYIITGFAAF IYAKTRLPFFAKGISLP

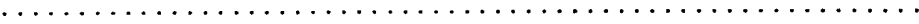

$\ldots \ldots \ldots \ldots \ldots \ldots \ldots \ldots$

YLVLVVGPFMILPNVGLNEWGHTFWFMEELFVAPLHYGFVIFGWLALAVMGTLTQTFYSF

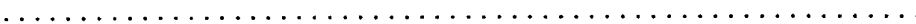

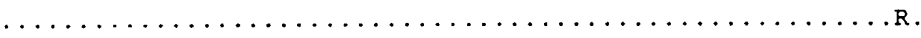

241 SHLFERD-LCPDIR 253

AQGGLGQS. . EAVDEGLIAK 260

AOGGLGQS. . EA
Fig. 2. Comparison of the three translated products of the pmoC genes. Periods denote residues identical to the $\mathrm{PmoC} 3$ sequence; $a$ dash denotes a gap.

\section{Construction of pmo gene disruptions and phenotypic characterization of mutants}

For the pmoA mutants, Km-resistance insertions were generated in the Sall site of pmoA1 in pAMC101, and were used in allelic exchange experiments to obtain insertions in the chromosome for both $p m o A 1$ and $p m o A 2$. For the $p m o C$ insertions, $\mathrm{Km}$-resistance insertions were generated in the BbsI site of pmoC1 in pAMC101, and were used to obtain insertions in the chromosome for both pmoC1 and pmoC2. For the $p m o B$ mutants, $\mathrm{Km}$-resistance insertions were generated in the $K p n I$ site of $p m o B 2$ in pAMC103, but in this case chromosomal insertions were only obtained in $p m o B 2$. Therefore, a second construction was generated with a $\mathrm{Km}$-resistance insertion in the $K p n \mathrm{I}$ site of $p m o B 1$ in pAMC102 and was used to generate chromosomal insertions in $p m o B 1$. Each of these recombination events was confirmed by hybridization and/or by PCR of specific pmo-Km cassette fragments. The hybridization experiments also confirmed previous results (Semrau et al., 1995) showing that two copies of $p m o A$ and $p m o B$ were present.

Mutants were isolated on plates designed either for pMMO or for sMMO expression, and tested for growth on both types of media. For pMMO expression, plates of NMS medium plus copper were used. For sMMO expression, several types of medium were tested with the wild-type, and it was determined by the naphthalene colorimetric assay that maximal sMMO expression could be achieved with NMS plates containing no added copper, but with added formate and iron (NMSF medium; see Methods). All of these mutants grew on methane on both types of media. On plates of NMSF medium, it was shown by the naphthalene colorimetric assay that the wild-type and the mutants exhibited substantial sMMO activity, which appeared similar by visual examination. On plates of NMS medium containing copper, none of the strains showed detectable sMMO activity, and were assumed to be expressing pMMO.

All of the mutants showed some genetic instability, due to recombination between the gene copies. Therefore, for phenotypic characterization, transfers were kept to a

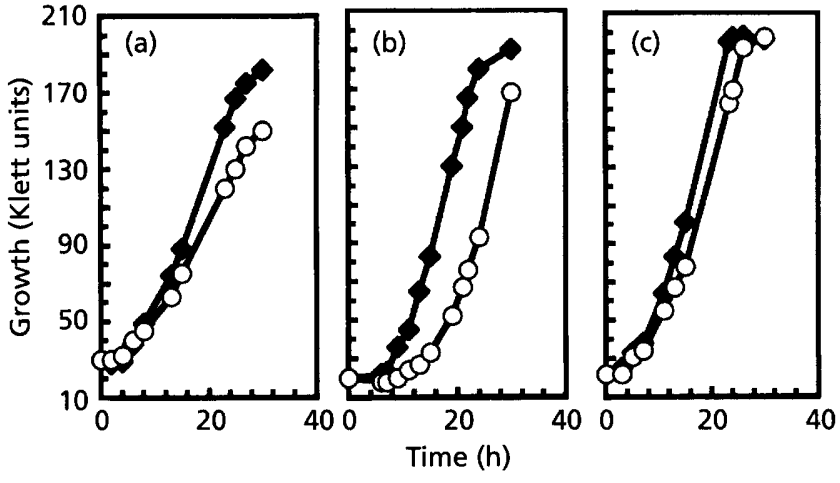

Fig. 3. Growth curves, determined from Klett readings with a no. 6 filter, of the insertion mutants for the pmo genes. (a) pmoC1: $\mathrm{Km}(\diamond)$ and $p m o C 2: \mathrm{Km}(\mathrm{O}) ;(\mathrm{b}) p m o A 1: \mathrm{Km}(\diamond)$ and pmoA2: $\mathrm{Km}(O) ;(c) p m o B 1: \mathrm{Km}(\diamond)$ and pmoB2: $\mathrm{Km}(O)$. Growth curves for the T401 strain (wild-type containing a Tn5 insertion) were the same as for the copy 1 mutants.

minimum and cultures were inoculated from plates that had been streaked directly from frozen stocks. To ensure that the cultures used for phenotypic characterization carried the appropriate mutation, all cultures were tested after growth for the correct insertion by diagnostic PCR.

In broth culture, the growth rate of the mutants defective in the copy 1 genes in the presence of kanamycin was not significantly different from that of a wild-type strain containing a Km-resistance marker, strain T401 (Fig. 3; Table 2). However, the growth rate of the mutants with insertions in the copy 2 genes was consistently $15-20 \%$ slower than the wild-type or the copy 1 mutants, and longer lag phases were common. Methane-dependent $\mathrm{O}_{2}$ uptake rates were determined in mutant and wildtype strains, as a measure of pMMO activity. Mutants in the copy 1 genes had rates that were $65-85 \%$ of the wild-type rate. However, mutants in copy 2 genes showed lower rates, $37-50 \%$ of the wild-type rate (Table 2).

Attempts were made to generate double mutants in pmoB using both $\mathrm{Km}-$ and $\mathrm{Sm}$-resistance cassettes. A 
Table 2. Doubling time and methane oxidation rates for wild-type and pmo mutants

\begin{tabular}{|lccc|}
\hline Strain & Affected gene & $\begin{array}{c}\text { Doubling time } \\
(\mathbf{h})^{*}\end{array}$ & $\begin{array}{c}\mathrm{CH}_{\mathbf{4}} \text { oxidation [nmol } \\
(\mathbf{m g} \text { protein })^{-1} \mathbf{m i n}^{-1} \text { ] }\end{array}$ \\
\hline T401 (Km' wild-type $)$ & & $7 \cdot 8 \pm 1 \cdot 0$ & 351 \\
MCK60 & pmoC1 & $6 \cdot 6 \pm 2 \cdot 1$ & 299 \\
MCK62 & pmoC2 & $9 \cdot 2 \pm 1 \cdot 3$ & 177 \\
MBK1-1 & pmoB1 & $8 \cdot 0 \pm 0 \cdot 4$ & 232 \\
MBK206 & pmoB2 & $9 \cdot 3 \pm 2 \cdot 1$ & 130 \\
MAK5 & pmoA1 & $5 \cdot 5 \pm 2 \cdot 1$ & 225 \\
MAKF016 & pmoA2 & $8 \cdot 8 \pm 1 \cdot 2$ & 165 \\
\hline
\end{tabular}

* Measurements are means and standard deviations for triplicate cultures grown in the presence of kanamycin.

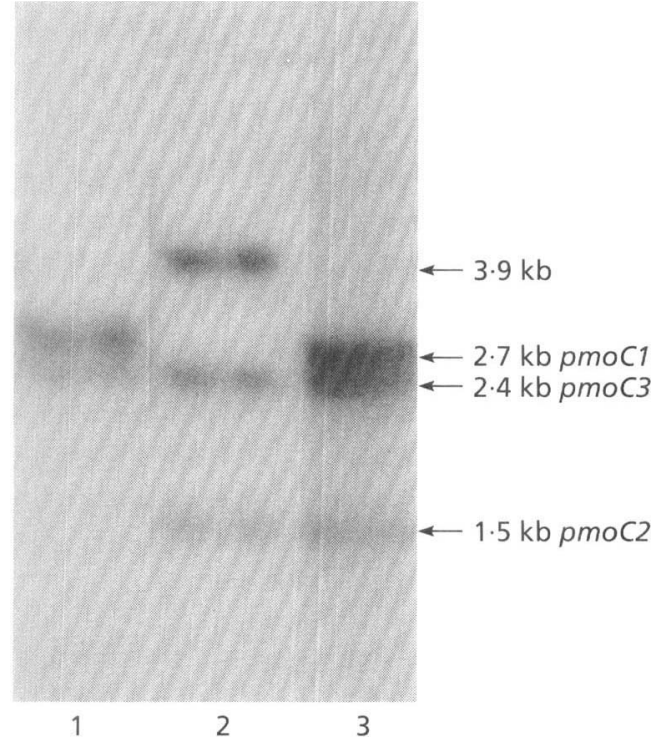

Fig. 4. DNA blot showing hybridization of Sall-digested $M$. capsulatus Bath chromosomal DNA to a pmoC1 probe (the Kpnl-Smal fragment of pAMC101). 1, MCK62 (pmoC2 insertion strain); 2, MCK60 (pmoC1 insertion strain); 3, wild-type.

Sm-resistance cassette was inserted into the MscI site within pmoB2 in pAMC103, and an EcoRI fragment with the disrupted $p m o B 2$ sequence was recloned into the suicide vector pAYC61. The MBK1-1 mutant carrying a $\mathrm{Km}$ insertion in $p m o B 1$ was used as a recipient, and selection was carried out on both NMS and NMSF plates. Although colonies were obtained on both types of media that were resistant to both $\mathrm{Sm}$ and $\mathrm{Km}$, most of them showed decreased growth on plates with each transfer, and were not viable after three to four transfers. Those that were able to grow through multiple transfers were Ap-resistant, suggesting they were single-crossover recombinants containing a complete $p m o B$ gene. Hybridization analysis confirmed the suspected recombination events (data not shown). When the same Sm-resistance construction was used in wildtype, double-crossover recombinants were obtained separately in $p m o B 1$ and $p m o B 2$, demonstrating that the Sm-resistance plasmid was functional for generating insertion mutations. These mutants were also used as recipients for constructions containing $\mathrm{Km}$ insertions into each $p m o B$ gene, and in these cases also, no Apsensitive clones were obtained.

\section{Third copy of pmoC}

As noted above, all of the insertion mutants were analysed by hybridization with probes for the genes that were disrupted and for the Km-resistance cassette. In the case of the $p m o A$ and $p m o B$ mutants, these experiments produced the expected results and confirmed the presence of two copies. However, hybridization of Salldigested $M$. capsulatus Bath chromosomal DNA to a pmoC1 probe (the KpnI-SmaI fragment of pAMC101) revealed three bands of hybridization of $1.5,2.4$ and $2.7 \mathrm{~kb}$ (Fig. 4). Because it was known that neither pmoC1 nor pmoC2 contained a Sall site, these results suggested the presence of a third copy of pmoC in the genome of $M$. capsulatus Bath. This idea was supported by results from hybridization of Sall-digested DNA from the insertion mutants MCK60 and MCK62, which contain a $\mathrm{Km}$-resistance insertion in pmoC1 and pmoC2, respectively. In the pmoC1 mutant, hybridization with the pmoC1 probe showed that the $2.7 \mathrm{~kb}$ band was increased in size about $1.3 \mathrm{~kb}$, as expected for the insertion, while the other two bands remained the same. In the pmoC2 mutant, hybridization with the same probe showed that the $1.5 \mathrm{~kb}$ band increased to about $2.8 \mathrm{~kb}$, as expected, and the other two bands remained the same, although the 2.7 and $2.8 \mathrm{~kb}$ bands were not well resolved (Fig. 4). These results suggested that the $2.4 \mathrm{~kb}$ band contained a third copy of pmoC. Sall-digested chromosomal DNA from the MCK60 mutant (containing an insertion in pmoC1) was hybridized with primers specific for pmoC sequence (CSS16R, CSS17R, CSSK4F, CSS9R and CSS10R) as well as the pmoA-specific primer ASS1F. As expected, all of the primers hybridized to the bands corresponding to copy 1 and copy 2, and most of the pmoC-specific primers hybridized to the $2.4 \mathrm{~kb}$ band containing the putative pmoC3. However, CSS17R and ASS1F did not hybridize 
to the $2.4 \mathrm{~kb}$ Sall fragment or to any new fragments. These results suggested that a third copy of $p m o A$ is not present and that significant divergence of the $p m o C 3$ sequence occurs in the $\mathrm{N}$-terminal region. Therefore, we used an inverse PCR strategy similar to that used for the copy 2 genes to obtain the $\mathrm{N}$-terminal, $\mathrm{C}$-terminal and upstream regions of $p m o C 3$.

Sall-digested DNA from MCK60 was ligated and redigested with AflIII. This DNA was used as a template for PCR with the CSS19R and CSS9F primers. A PCR product of the predicted size was obtained, cloned into pCR2.1 vector and sequenced, providing the sequence of the flanking regions. PCR primers (C3F1 and C3R1, see Methods) were then designed to amplify the whole ORF of pmoC3 and complete the sequence. An ORF of 253 amino acids was identified with high identity to the other copies of $p m o C$ in the central region but containing divergence at the $\mathrm{N}$ - and C-termini (Fig. 2).

The entire ORF for $p m o C 3$ was generated by PCR and cloned into the pCR2.1 vector. However, only plasmids containing pmoC3 in the orientation opposite to the direction of transcription from the pCR2.1 lac promoter were obtained. Attempts were made to generate insertion mutations in pmoC3, using the BbsI site for a $\mathrm{Km}^{\mathrm{r}}$ cassette and the cloned PCR product containing the entire pmoC3. Matings were tested on both NMS plates with copper (for pMMO expression) and NMSF plates (for sMMO expression). However, only single-crossover insertions were obtained, which generated an intact pmoC3. These mutants grew normally on methane.

\section{DISCUSSION}

The results in this report complete the sequence of two sets of $p m o C A B$ genes, and provide the sequence of a third copy of $p m o C$. For the first two sets, the sequences are almost identical within the coding and intergenic regions, but they diverge outside the $p m o C A B$ regions. For pmoC3, the sequence diverges in the $\mathrm{N}$ - and $\mathrm{C}$ terminus of the encoded protein (Fig. 2). The genetic organization and numbers of gene copies for this pmo system are highly similar to those observed for amo genes in Nitrosomonas europaea (Hommes et al., 1998; Sayavedra-Soto et al., 1998), but other nitrifiers have three sets of amo genes (Norton et al., 1996; SayavedraSoto et al., 1998). The role of these multiple gene copies has not been well understood in either methanotrophs or nitrifiers. Methanotrophs such as M. capsulatus Bath have two alternative methane oxidation systems, the pMMO and the sMMO. Therefore, the physiological role of pMMO is different in these methanotrophs from that of ammonia monooxygenase in nitrifiers, since nitrifiers do not contain an alternative ammonia oxidation system.

In this study, double-crossover insertion mutants were isolated for each pmo gene found in the two sets of complete $p m o C A B$ clusters, to assess the contribution of each gene copy to pMMO activity. These mutants all grew on methane in the presence of copper and in the absence of detectable sMMO expression, suggesting that pMMO must be produced from each set of genes under these growth conditions. This conclusion is confirmed by the results of the methane oxidation rate experiments in mutants and wild-type, which showed that about a third of the whole-cell methane oxidation is due to copy 1 genes, while about two-thirds is due to copy 2 genes. The presence of the two copies of pmo genes apparently gives the cells excess methane oxidation capacity, since impairment of the copy 1 genes did not affect growth. However, impairment of the copy 2 genes did result in a small growth defect, suggesting that cells need the copy 2 gene expression for normal growth.

These results are similar in some respects to the results obtained so far for the amo system in nitrifying bacteria. In $N$. europaea, mutants have only been generated in amoA gene copies, so no information is available for $a m o B$ or $a m o C$ mutants. For amo $A$, mutants defective in each gene were viable, but mutants in one copy showed decreased growth while the other mutants showed normal growth (Hommes et al., 1998), similar to the results we report here for $p m o A$ mutants. However, in the nitrifier the whole-cell ammonia oxidation rate did not change significantly in the mutant with normal growth rate, suggesting that under these conditions the wild-type ammonia monooxygenase activity could be sustained by the other gene copy. This is in contrast to our results, in which both copies are required to maintain wild-type pMMO activity.

Since the two clusters of pmo genes are so similar in sequence, it seems likely that the enzymes produced from each copy have a similar function. Therefore, the role of the duplicate gene clusters may be simply to provide increased gene expression, although it appears that this higher level of pMMO activity is not necessary for maximal growth under laboratory conditions. It may be that the two copies are important for different types of growth conditions, for instance under stress conditions that might be encountered in the natural environment. It is also possible that the two copies are differentially expressed under different growth conditions, since the sequences upstream of pmoC1 and $p m o C 2$ are highly divergent. Further work involving promoter identification and expression will be required to resolve these questions.

We have also examined $p m o C 3$, since the role of this separate $p m o C$ gene is unknown and in $M$. capsulatus Bath it has a more divergent sequence than the other two pmoC copies. However, we were unable to isolate a null mutant in pmoC3. We cannot be certain whether this failure is due to an unknown technical problem that caused double-crossover recombination to occur at extremely low frequencies, or whether it is due to the essential nature of pmoC3 under the tested growth conditions. However, since we were able to isolate null mutants in $p m o C 1$ and $p m o C 2$ using a similar procedure and similar constructions, it is likely that pmoC3 null mutants are not viable. Therefore, our results suggest that $p m o C 3$ has an essential function in methane oxidation separate from the function of $p m o C 1$ and 
pmoC2. The role of this separate copy of $p m o C$ is not yet clear, but it probably fulfils a function necessary for generating active pMMO from both pmo clusters. It is unlikely that this function is to provide PmoC for $\mathrm{pMMO}$, since the major transcript from the two clusters contains all three genes ( $p m o C A B)$ and it is likely that all three are translated (Nielsen et al., 1997).

Since $M$. capsulatus Bath contains an alternative methane oxidation system (sMMO), it should be possible to obtain a pMMO-negative strain under conditions in which sMMO is expressed. We developed plate growth conditions that maximized expression of sMMO, and attempted to generate a double mutant that contained double-crossover (null) mutations in both $p m o B$ genes. However, all isolates always contained one wild-type $p m o B$, the result of a single-crossover recombination event. It is unlikely in this case that a technical problem occurred, because null mutants were readily obtained in each $p m o B$ copy individually using both markers. Similar attempts to obtain double mutants in $p m o A$ were also unsuccessful (unpublished data). It is known that $M$. capsulatus Bath can grow quite well in broth culture under conditions in which sMMO is the dominant methane oxidation enzyme, with only a small amount of pMMO present (Prior \& Dalton, 1985a; Zahn \& DiSpirito, 1996). Therefore, it is not clear why null mutants could not be obtained on plates. It is possible that the sMMO levels achieved on plates were too low to allow for growth, although they appeared to be substantial as judged by the colorimetric plate assay. Alternatively, it is possible that low level pMMO expression is required for growth on methane on plates even when sMMO is expressed.

\section{ACKNOWLEDGEMENTS}

This research was supported by a grant from the NSF (MCB9630645) and a University Research Initiative grant from ARPA (N00014-92-J-1901). The plasmid pBR325 $\Omega$ was kindly provided by $\operatorname{Dr}$ J. C. Murrell. We thank Drs L. Chistoserdova, R. Meima and H. Toyama for helpful discussions.

\section{REFERENCES}

Altschul, S. F., Gish, W., Miller, W. \& Myer, E. W. (1990). Basic local alignment search tool. J Mol Biol 215, 403-410.

Altschul, S. F., Madden, T. L., Schaffer, A. A., Zhang, J., Zhang, Z., Miller, W. \& Lipman, D. J. (1997). Gapped BLAST and PSI-BLAST: a new generation of protein database search programs. Nucleic Acids Res 25, 3389-3402.

Bolivar, F. (1978). Construction and characterization of new cloning vehicles. 3. Derivatives of plasmid pBR322 carrying unique EcoRI site for selection. Gene 4, 121-136.

Cardy, D. L. N., Laidler, V., Salmond, G. P. C. \& Murrell, C. J. (1991). Molecular analysis of the methane monooxygenase (MMO) gene cluster of Methylosinus trichosporium OB3b. Mol Microbiol 5, 335-342.

Chistoserdov, A. Y., Mclntire, W. S. \& Lidstrom, M. E. (1994). Genetic organization of the mau gene cluster in Methylobacterium extorquens AM1: complete nucleotide sequence and generation and characterization of mau mutants. J Bacteriol 176, $4052-4065$.

Colby, J. \& Dalton, H. (1976). Some properties of a soluble methane mono-oxygenase from Methylococcus capsulatus strain Bath. Biochem J 157, 495-497.

DiSpirito, A. A., Gulledge, J., Murrell, J. C., Shiemke, A. K., Lidstrom, M. E. \& Krema, C. L. (1992). Trichloroethylene oxidation by the membrane associated methane monooxygenase in type I, type II and type X methanotrophs. Biodegradation 2, 151-164.

Figurski, D. H. \& Helinski, D. R. (1979). Replication of an origincontaining derivative of plasmid RK2 dependent on a plasmid function provided in trans. Proc Natl Acad Sci USA 77, 7347-7357.

Fox, B. G., Froland, W. A., Dege, J. E. \& Lipscomb, J. D. (1989). Methane monooxygenase from Methylosinus trichosporium OB3b. Purification and properties of a three-component system with high specific activity from a type II methanotroph. $J$ Biol Chem 264, 10023-10033.

Graham, D. W., Korich, D. G., LeBlanc, R. P., Sinclair, N. A. \& Arnold, R. G. (1992). Applications of a colorimetric plate assay for soluble methane monooxygenase activity. Appl Environ Microbiol 58, 2231-2236.

Green, J. \& Dalton, H. (1989). Substrate specificity of soluble methane monooxygenase: mechanistic implications. J Biol Chem 264, 17698-17703.

Hanson, R. S., Netrusov, A. I. \& Tsuji, K. (1990). The obligate methanotrophic bacteria Methylococcus, Methylomonas, and Methylosinus. In The Prokaryotes, 2nd edn, pp. 2350-2364. Edited by A. Balows, H. G. Trüper, M. Dworkin, W. Harder \& K.-H. Schleifer. New York: Springer.

Hommes, N. G., Sayavedra-Soto, L. A. \& Arp, D. J. (1998). Mutagenesis and expression of amo, which codes for ammonia monooxygenase in Nitrosomonas europaea. J Bacteriol 180, 3353-3359.

Klotz, M. G., Alzerecca, J. \& Norton, J. M. (1997). A gene encoding protein exists upstream of the $a m o A / a m o B$ genes in ammonia oxidizing bacteria: a third member of the amo operon? FEMS Microbiol Lett 150, 65-73.

Koh, S.-C., Bowman, J. P. \& Sayler, G. S. (1993). Soluble methane monooxygenase production and trichloroethylene degradation by a type I methanotroph, Methylomonas methanica 68-1. Appl Environ Microbiol 59, 960-967.

McDonald, I. R., Uchiyama, H., Kambe, S., Yagi, O. \& Murrell, J. C. (1997). The soluble methane monooxygenase gene cluster of the trichloroethylene degrading methanotroph Methylocystis sp. strain M. Appl Environ Microbiol 63, 1898-1904.

McNerney, T. \& O'Connor, M. L. (1980). Regulation of $C_{1}$ enzymes in three facultative methylotrophs. Appl Environ Microbiol 40, 370-375.

McTavish, H., Fuchs, J. A. \& Hooper, A. B. (1993). Sequence of the gene coding for ammonia monooxygenase in Nitrosomonas europaea. J Bacteriol 175, 2436-2444.

Marmur, J. (1961). A procedure for the isolation of deoxyribonucleic acid from microorganisms. J Mol Biol 3, 208-218.

Martin, H. \& Murrell, J.C. (1995). Methane monooxygenase mutants of Methylosinus trichosporium constructed by markerexchange mutagenesis. FEMS Microbiol Lett 127, 243-248.

Meinkoth, J. \& Wahl, G. (1984). Hybridization of nucleic acids immobilized on a solid support. Anal Biochem 138, 267-284.

Nakajima, T., Uchiyama, H., Yagi, O. \& Nakahara, T. (1992). Purification and properties of a soluble methane monooxygenase 
from Methylocystis sp. M. Biosci Biotechnol Biochem 56, 736-740.

Nguyen, H.-H. A. T., Shiemke, A. K., Jacobs, S. J., Hales, B. J., Lidstrom, M. E. \& Chan, S. I. (1994). The nature of the copper ions in the membranes containing the particulate methane monooxygenase from Methylococcus capsulatus (Bath). J Biol Chem 269, 14995-15005.

Nguyen, H.-H. A. T., Elliot, S. J., Kent, B. H. \& 10 other authors (1996). The biochemistry of the particulate methane monooxygenase. In Microbial Growth on $C_{1}$ Compounds, pp. 150-158. Edited by M. E. Lidstrom \& F. R. Tabita. Dordrecht: Kluwer.

Nguyen, H.-H. A. T., Elliot, S. J., Yip, J. H. K. \& Chan, S. I. (1998). The particulate methane monooxygenase from Metbylococcus capsulatus (Bath) is a novel copper-containing three-subunit enzyme - isolation and characterization. J Biol Chem 272, $7957-7966$.

Nielsen, A. K., Gerdes, K. \& Murrell, J. C. (1997). Copperdependent reciprocal transcriptional regulation of methane monooxygenase genes in Methylococcus capsulatus and Metbylosinus trichosporium. Mol Microbiol 25, 399-409.

Norton, J. M., Jackie, M. L. \& Klotz, M. G. (1996). The gene encoding ammonia monooxygenase subunit $A$ exists in three nearly identical copies in Nitrosospira sp. NpAV. FEMS Microbiol Lett 139, 181-188.

Prentki, P. \& Krisch, H. M. (1984). In vitro insertional mutagenesis with a selectable DNA fragment. Gene 29, 303-313.

Prior, S. D. \& Dalton, H. (1985a). The effect of copper ions on membrane content and methane monooxygenase activity in methanol-grown cells of Methylococcus capsulatus (Bath). J Gen Microbiol 131, 155-163.

Prior, S. D. \& Dalton, H. (1985b). Acetylene as a suicide substrate and active site probe for methane monooxygenase from Methylococcus capsulatus (Bath). FEMS Microbiol Lett 29, 105-109.

Sambrook, J., Fritsch, E. F. \& Maniatis, T. (1989). Molecular Cloning: a Laboratory Manual, 2nd edn. Cold Spring Harbor, NY: Cold Spring Harbor Laboratory.
Sayavedra-Soto, L. A., Hommes, N. G., Alzerreca, J. J., Arp, D. J., Norton, J. M. \& Klotz, M. G. (1998). Transcription of the amoC, amoA and amoB genes in Nitrosomonas europaea and Nitrosospira sp. NpAV. FEMS Microbiol Lett 167, 81-88.

Semrau, J. D., Chistoserdov, A., Lebron, J. \& 7 other authors (1995). Particulate methane monooxygenase genes in methanotrophs. J Bacteriol 177, 3071-3079.

Simon, R., Priefer, U. \& Puhler, A. (1983). A broad host range mobilization system for in vivo genetic engineering: transposon mutagenesis in Gram-negative bacteria. Bio/Technology 1, $37-45$.

Smith, D. D. \& Dalton, H. (1989). Solubilization of methane monooxygenase from Methylococcus capsulatus (Bath). Eur J Biochem 182, 667-671.

Stainthorpe, A. C., Lees, V., Salmond, G. P. C., Dalton, H. \& Murrell, J. C. (1990). The methane monooxygenase gene cluster of Methylococcus capsulatus (Bath). Gene 91, 27-34.

Stolyar, S. M., Romanovskaya, V. A. \& Malashenko, Y. R. (1995). Search for systems of genetic exchange in methane-oxidizing bacteria. Microbiology (English translation of Mikrobiologiya) 64, 584-588.

Vieira, J. \& Messing, J. (1982). The pUC plasmids, an M13mp7derived system for insertion mutagenesis and sequencing with synthetic universal primers. Gene 19, 259-268.

Whittenbury, R. \& Dalton, H. (1981). The methylotrophic bacteria. In The Prokaryotes, pp. 894-902. Edited by M. Starr, H. Stolp, H. Trüper, A. Balows \& H. Schlegel. Berlin: Springer.

Yanisch-Perron, C., Vieira, J. \& Messing, J. (1985). Improved M13 phage cloning vectors and host strains: nucleotide sequences of the M13mp18 and pUC19 vectors. Gene 33, 103-119.

Zahn, J. A. \& DiSpirito, A. A. (1996). Membrane-associated methane monooxygenase from Methylococcus capsulatus (Bath). J Bacteriol 178, 1018-1029.

Received 13 January 1998; accepted 28 January 1999. 